\title{
Experience of emergency organization of distance learning for police managers
}

\author{
Galina Pyrchenkova ${ }^{1}$, and Elena Radchenko ${ }^{2 *}$ \\ ${ }^{1}$ Academy of Management of the Ministry of Internal Affairs of Russia, Moscow, Russia \\ ${ }^{2}$ Research Institute of the Federal Penitentiary Service of Russia, Moscow, Russia
}

\begin{abstract}
The article is devoted to the analysis of the experience of organization of distance learning for police leadership in a higher education institution in the emergency situation. The authors examine the advantages and disadvantages of creating a digital educational environment for police managers from the point of view of the students as well as the teaching staff of the Academy of Management of the Ministry of Internal Affairs of Russia. The conclusions arising from these opinions along with various aspects of the emergency arrangement of teaching higher educational programs in a remote access mode are examined. The authors focus attention on the evaluation of the organization and content of the distance learning course, including the analysis of the level of readiness of the teachers of the educational organization to conduct training sessions in a distance mode; the assessment of the students' abilities for selforganization and e-learning; the quality of the pedagogical control of the current and final academic performance of the students in a remote mode and the objectivity of the assessments made during the intermediate testing and final examination etc. The authors identify positive and negative aspects of the experience of emergency organization of distance learning for police leaders.
\end{abstract}

\section{Introduction}

The formation of a single global information and educational space results in the appearance of new pedagogical technologies for teaching educational programs in higher education institutions. New approaches to the formation of a digital educational space are reflected in the Bologna Declaration, which promotes the widespread introduction of information and communication technologies in the field of higher education. In our country the main ideas of the development of digital education technologies are stipulated by the Federal Law «On Education in the Russian Federation». The Decree of the President of the Russian Federation No. 204 has identified the strategic goals for the development of innovative methods for the organization of the learning process in higher education institutions. In the face of these new challenges there is a need to train police managers' practical skills in using the resources of the information and communication system and elearning technologies. To achieve the stated goal the Academy of Management of the

* Corresponding author: helenr2003@mail.ru 
Ministry of Internal Affairs of Russia (hereinafter referred to as the Academy) has developed a program aimed at the training of highly qualified police managers well versed in modern digital learning technologies. This task has become all the more urgent during the extreme situation of the spread of a new infection - Covid 19. Given the fact that the Academy is the leading departmental higher education institution, the experience of organizing e-learning for police leadership at the Academy acquires especial significance.

\section{Problem statement}

Considering all of the above, the process of organizing high-quality implementation of higher educational programs in a remote access mode becomes a priority. This issue is of particular importance especially in the period of emergency situations, which involves special conditions for the transition from the traditional form of teaching educational programs to e-learning. Due to the threat of a new coronavirus infection, the representatives of the world scientific and pedagogical community had to look for the new digital methods of providing knowledge to the students of higher education institutions.

In this regard we should mention the works of domestic scientists devoted to various aspects of organizing the teaching process in a remote mode and improving its quality and effectiveness: Urintsov et.al., Nazarenko, Babanskaya et.al., Matveeva et.al., Skorikova, Khromov \& Dneprovskaya, Leontyeva, Lomonosova [1-7]. Most of the representatives of the Russian scientific world identify the higher e-education as an innovative method of interactive communication between teachers and students in a digital environment, which stimulates the students' abilities to acquiring knowledge in a new digital way: Osipova \& Goreva, Kuznetsova, Pavlutskaya \& Dubitskaya [8-10].

Issues of development and implementation of innovative digital pedagogical technologies have been the subject of investigation of a number of foreign scientists. These researchers focus on various approaches to organizing widespread introduction of information and communication technologies in the field of education: White, Sole, \& Hopkins, Hanson, Mohr, Holtbrügge, \& Berg, Peters \& Jandric, Schneider, Tsai \& Tsai [11-17]. At the present stage of the development of the digital educational space the foreign scientists are actively researching into the peculiarities of mixed (traditional and distance) teaching of higher educational programs: Jones \& Sharma, Wang \& Huang, Baragash \& Al - Samarraie et al. [18-20]. We should also state that some foreign authors also consider the assessment of e-learning process from the students' point of view: Hilgenberg, \& Tolone, Sampson, Işık, Karakış, \& Güler, Rashid, Khokhar, \& Tahir, Emrah [21-25].

However, despite the considerable interest of the world scientific community in the issues of creating conditions for the successful organization of teaching higher educational programs in a remote access mode, the positive and negative outcomes of the emergency organization of e-learning process of a higher education institution, have not yet been sufficiently studied. Moreover, the question of how the innovative digital pedagogical technologies applied in the field of higher education in emergency situations meet the expectations and needs of both, the students and the teachers, also remains poorly understood. In this regard, it is expedient to research into the above-mentioned issues in order to determine the key problems and the ways to overcome the negative aspects.

\section{Research questions}

The transition to e-learning in emergency situation has revealed a number of positive and negative outcomes of the educational process which require the necessity to answer some questions, such as: 
a. Does distance learning lead to a full-fledged mastering of the higher educational programs?

b. Do educators have the necessary skills to operate the digital learning environment?

c. Are the training materials for e-learning as effective as the materials developed by the teaching staff for classroom classes?

d. Is it possible to provide high-quality pedagogical control of the knowledge acquired by the students?

e. What should be done to improve the quality of distance learning? etc.

\section{Purpose of the study}

The main purpose of the study is to evaluate the experience of the emergency organization of teaching higher educational programs in a remote mode and to determine if the elearning courses meet the needs of the students of the Academy of Management of the Ministry of Internal Affairs of Russia as well as the requirements of its teaching staff. The authors concentrate on the students' and teachers' assessment of the organization and implementation of digital educational environment, including the analysis of the content of e-education, the role and contribution of educators in the process of e-training, the students' abilities for self-organization and the independent acquisition of knowledge in a remote access mode etc. The authors will also try to detect the positive and negative aspects of the organization of distance learning for police managers in the emergency situation and propose some ways to overcome the shortcomings.

\section{Research methods}

This study is a continuation of the investigation of the advantages and disadvantages of organizing a high-quality digital educational environment in emergency situation at the Academy of Management of the Ministry of Internal Affairs of Russia. At the preliminary stages of the research the authors analyzed the advantages and disadvantages of the realization of the academic higher educational programs in a remote mode from the point of view of the Academy students (the 1st stage of the research) and the Academy teaching staff (the 2 nd stage of the research). At this stage of the investigation the authors will focus on the comparison of students' and teachers' assessments of the organization and implementation of digital education in the emergency situation [26].

To achieve the stated goal the authors conducted a pedagogical experiment (questionnaire study) during which 73 students and 24 teachers of the Academy were interviewed in the videoconference mode to receive answers to key questions. Data were collected and examined using a 10-point questionnaire developed on the basis of the Likert scale. While working with a questionnaire, the respondents evaluated the degree of their agreement or disagreement with each statement, from 1. - excellent, 2.- very good, 3. good, 4. - satisfactory, 5. - unsatisfactory. This rating scale allowed us to determine the attitude of each respondent to each individual statement. The sum of the assessments of each individual judgment allowed us to identify the overall assessment of issues by the respondents.

During the experiment, an unstructured survey of respondents was also conducted to identify the most important positive and negative aspects of the emergency organization and implementation of e-learning from the respondents' point of view. The results of the investigation are graphically displayed in this study. 


\section{Findings}

Despite of the fact that the Academy has been developing distance learning pedagogical technologies for a number of years, the academic educators as well as the students faced a number of problems during the unplanned transition to e-learning in the context of the coronavirus pandemic. The emergency transition to e-education has revealed both, the positive and the negative aspects of this process. Having conducted the above-mentioned pedagogical experiment (questionnaire study) involving 73 students and 24 teachers of the Academy, the authors came to the conclusions reflected in the following tables:

Table 1. Assessment of the implementation of the educational program in the remote mode by the students of the Academy of Management of the Ministry of Internal Affairs of Russia.

\begin{tabular}{|c|c|c|c|c|c|}
\hline $\begin{array}{c}\text { Statement } \\
\text { Excellent }\end{array}$ & Very good & Good & $\begin{array}{c}\text { Satisfacto } \\
\text { ry }\end{array}$ & $\begin{array}{c}\text { Unsatisfact } \\
\text { ory }\end{array}$ \\
\hline $\begin{array}{c}\text { 1. The realization of the } \\
\text { remote mode can be } \\
\text { generally evaluated as }\end{array}$ & $20 \%$ & $59 \%$ & $13 \%$ & $8 \%$ & - \\
\hline $\begin{array}{c}2 . \text { The organization of the } \\
\text { distance learning course can } \\
\text { be assessed as ... }\end{array}$ & $15 \%$ & $45 \%$ & $28 \%$ & $12 \%$ & - \\
\hline $\begin{array}{c}\text { 3. The content of } \\
\text { educational and } \\
\text { methodological material for } \\
\text { conducting training sessions } \\
\text { can be evaluated as .. }\end{array}$ & $8 \%$ & $33 \%$ & $50 \%$ & $9 \%$ & - \\
\hline $\begin{array}{c}4 . \text { The content of the } \\
\text { educational material for } \\
\text { self-study can be evaluated } \\
\text { as ... }\end{array}$ & $36 \%$ & $52 \%$ & $10 \%$ & $2 \%$ & - \\
\hline $\begin{array}{c}5 . \text { The efficiency of the use } \\
\text { of multimedia means of the } \\
\text { presentation of educational } \\
\text { material can be evaluated as } \\
\text {... }\end{array}$ & $4 \%$ & $41 \%$ & $44 \%$ & $11 \%$ & - \\
\hline $\begin{array}{c}\text { 6. The level of a teacher's } \\
\text { readiness to conduct } \\
\text { lectures, seminars and } \\
\text { practical classes in remote } \\
\text { mode generally can be } \\
\text { estimated as ... }\end{array}$ & $6 \%$ & $59 \%$ & $27 \%$ & $8 \%$ & \\
\hline $\begin{array}{c}7 . \text { Pedagogical control of } \\
\text { the current and final } \\
\text { academic performance of } \\
\text { students in remote mode } \\
\text { can be assessed as ... }\end{array}$ & $16 \%$ & $56 \%$ & $28 \%$ & - & \\
\hline & & & & & \\
\hline
\end{tabular}


Table 2. Assessment of the implementation of the educational program in the remote mode by the teachers of the Academy of Management of the Ministry of Internal Affairs of Russia.

\begin{tabular}{|c|c|c|c|c|c|}
\hline Statement & Excellent & Very good & Good & $\begin{array}{c}\text { Satisfacto } \\
\text { ry }\end{array}$ & $\begin{array}{c}\text { Unsatisfact } \\
\text { ory }\end{array}$ \\
\hline $\begin{array}{c}\text { 1. The realization of the } \\
\text { educational program in } \\
\text { remote mode can be } \\
\text { generally evaluated as }\end{array}$ & $14 \%$ & $62 \%$ & $13 \%$ & $11 \%$ & - \\
\hline $\begin{array}{c}\text { 2. The organization of the } \\
\text { distance learning course can } \\
\text { be assessed as ... }\end{array}$ & $9 \%$ & $56 \%$ & $25 \%$ & $10 \%$ & - \\
\hline $\begin{array}{c}3 . \text { The content of educational } \\
\text { and methodological material } \\
\text { for conducting training } \\
\text { sessions can be evaluated as } \\
\ldots\end{array}$ & $3 \%$ & $22 \%$ & $54 \%$ & $21 \%$ & - \\
\hline $\begin{array}{c}4 . \text { The content of the } \\
\text { educational material for self- } \\
\text { study can be evaluated as .. }\end{array}$ & $27 \%$ & $52 \%$ & $17 \%$ & $4 \%$ & - \\
\hline $\begin{array}{c}5 . \text { The efficiency of the use } \\
\text { of multimedia means of the } \\
\text { presentation of educational } \\
\text { material can be evaluated as } \\
\ldots\end{array}$ & $4 \%$ & $31 \%$ & $44 \%$ & $21 \%$ & - \\
\hline $\begin{array}{c}\text { 6. The level of a teacher's } \\
\text { readiness to conduct lectures, } \\
\text { seminars and practical } \\
\text { classes in remote mode } \\
\text { generally can be estimated as } \\
\ldots\end{array}$ & - & $25 \%$ & $49 \%$ & $26 \%$ & \\
\hline $\begin{array}{c}\text { 7. Pedagogical control of the } \\
\text { current and final academic } \\
\text { performance of students in } \\
\text { remote mode can be assessed } \\
\text { as }\end{array}$ & $3 \%$ & $13 \%$ & $54 \%$ & $30 \%$ & - \\
\hline
\end{tabular}

As it is reflected in tables 1 and 2, the overwhelming majority of the Academy students (79 \%) and teachers (76\%) expressed the opinion that the implementation of the educational program in the remote mode was generally successful and can be rated «excellent» and «very good», which indicates a relatively sufficient level of readiness of the educational organization to switch to remote mode of education in an extreme situation.

The majority of students $(60 \%)$ and teachers $(65 \%)$ also rated the organization of the distance learning course as «excellent» and «very good». However, the remaining respondents believe that the organization of the training course was less successful and deserves marks "good" (28\% of students and $35 \%$ of teachers)) and "satisfactory" (12\% of students and $10 \%$ of teachers). These results require from the academic staff to revise a number of organizational issues in order to develop appropriate decisions.

As shown in the tables, half of the students $(50 \%)$, in general, were satisfied with the content of the educational material for conducting training sessions in the remote mode. However, the fact that $41 \%$ of the students estimated the content of the educational material for conducting digital training sessions as «good» and «satisfactory» cannot be ignored by the teaching staff of the Academy. It seems even more important considering the fact that $75 \%$ of the educators evaluated the content of educational and methodological 
material for conducting digital training sessions and video lectures as "good" and "satisfactory." Only less than half of the teachers (25\%) expressed their satisfaction with the content of the educational and methodological material for conducting training sessions and video lectures in the remote mode, assessing it as "excellent" and "very good". This result is due to the fact that most of this material was developed for teaching in the classrooms of the Academy. Therefore we should state that there is a necessity to substantially revise educational and methodological material for conducting digital training sessions and video lectures, regarding such requirements of e-learning, as psychological peculiarities of the perception of educational information by the students in a remote mode, increased level of independent acquisition of new knowledge by the students, changing the role of the teacher in the educational process, etc.

Further analysis has shown that the Academy students appreciated the content of the educational material for self-study ( $88 \%$ ) and the effectiveness of video lectures conducted by the teaching staff of the educational organization. This is also evidenced by the ratings of $79 \%$ of the teachers who believe that the content of educational and methodological material for independent work can be assessed as «excellent» and «very good».

At the same time, it should be stated that more than half of the students $(55 \%)$ evaluated the effectiveness of the multimedia presentation of educational material in the remote mode at a relatively low level: «good» $(44 \%)$ and «satisfactory» $(11 \%)$. This opinion is definitely shared by the representatives of the teaching staff of the Academy who rated the efficiency of the application of multimedia presentation of educational material while conducting practical classes, seminars and lectures in the remote mode as: "good" (44 $\%)$ and "satisfactory" (21\%). Thus, the practice of distance implementing of multimedia means of educational material presentation has shown the necessity to adopt it to the requirements of the digital educational environment, the individual abilities of the students and the needs of the entire group.

As shown in the table 1 , the vast majority of the Academy students (81\%) highly appreciated the level of a teacher's readiness to conduct lectures, seminars and practical classes in the remote mode and assessed the rating «excellent» and «very good». On the other hand, despite the work organized by the management of the Academy to instruct teachers to work remotely, the authors have discovered that, in general, teachers do not evaluate their readiness to work remotely at a high level. As it follows from the table 2, only $25 \%$ of the respondents rated their readiness to work in a remote access mode as "very good". At the same time, $75 \%$ of the respondents believe that the degree of their readiness for e-education can be assessed only as "good" and "satisfactory", which necessitates further search for solutions to improve the level of teachers' training to work in a digital educational environment.

Pedagogical monitoring of the students' current and final academic performance in the remote mode has received quite high ratings from the students $(84 \%$ of the respondents rated it «very good» and «good») and relatively high marks from the teachers (67\% of the respondents gave marks "very good" and "good"). However, only $3 \%$ of the teachers evaluated the level of the pedagogical control as an "excellent" one, and $30 \%$ of the respondents rated it as "satisfactory" one. These results demonstrate the insufficient degree of the development of the assessment tools for monitoring students' knowledge. Comparing the results of these assessments is a source of concern for teachers who should revise the tools for monitoring students' knowledge and formation of their educational and professional competencies.

We also have to acknowledge that one of the most positive signs of e-education is the high level of objectivity of the assessments made by the teachers during the intermediate testing and final examination of the students in a remote mode. At the preliminary stage of the investigation this aspect of e-learning has been estimated by the $97 \%$ of the students as 
«excellent» and «very good». The maximum objective nature of teachers' assessments of students' knowledge is obviously the result of such an important positive component of elearning process as exclusion of corruption. In this regard, we would like to note that this component of e-learning process has not yet been widely reflected in the works of domestic and foreign researchers.

On the other hand, the representatives of the Academy teaching staff indicated then such a negative side of emergency transition to e-learning as the relatively low level of selforganization of the students in the process of mastering the educational program in the distance mode: $36 \%$ of the respondents rated it as "very good", $47 \%$ of the respondents assessed it as "good", $17 \%$ of the respondents estimated it as "satisfactory." Considering that the readiness of the students to study the educational material independently in a remote mode is one of the most important components of the implementation of the educational program in the distance mode, the results obtained indicate that not all the students demonstrate a sufficient level of conscious attitude to distance learning and motivation to obtain high educational results.

In the course of the experiment an unstructured survey was also conducted with the same respondents, who were asked to identify three most important advantages and disadvantages of mastering the educational program in the remote mode from the following list:

advantages:

- a new role of the teacher - the coordinator of the cognitive process;

- absence of time and spatial restrictions;

- a high degree of self-organization and independence of students;

- opportunity for the independent acquisition of new knowledge;

- opportunity to continue training without interrupting professional duties;

- ability to determine the speed of learning the material, corresponding to the peculiarities of thinking;

- increasing the level of student's responsibility for the outcomes of learning.

disadvantages:

- inability to implement the dialogue between the teacher and students, adopted in the traditional form of education;

- lack of sufficient control over the knowledge received;

- reduction of the volume of educational material and time spent on its study;

- lack of appropriate teacher training;

- lack of interpersonal communication during the lesson and opportunities for comparing the results of a

- student's training with the results of other students in the group;

- lack of a quality level video conferencing during periods of the high server load;

- unavailability of the regulatory framework;

- increase in intellectual, physical and mental load.

During the unstructured survey of the respondents of the academy the authors tried to identify, evaluate and compare the most important advantages and disadvantages of the emergency organization of e-learning course from the students' and teachers' point of view. The results of the survey are graphically displayed in Figures 1, 2, 3 and 4. 


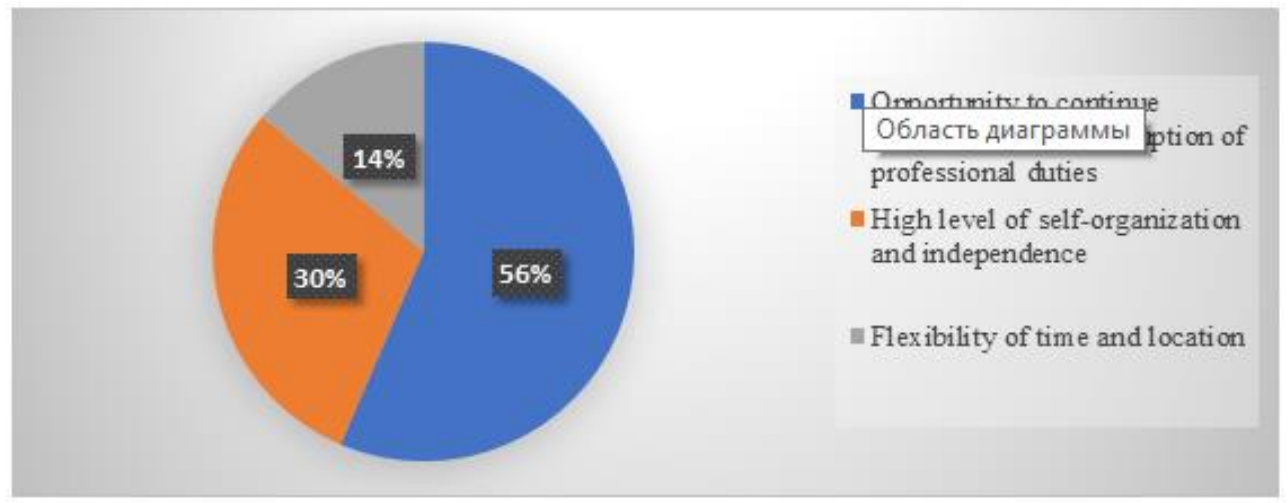

Fig. 1. The most important advantages of mastering the educational program in the remote mode from the point of view of students of the Academy of Management of the Ministry of Internal Affairs of Russia.

As it can be seen from the diagram, the most valuable parameters of e-learning for the students is the ability to organize the educational process without interrupting professional duties at a convenient time and place for them to work with educational material (56\% of respondents). Among the advantages of e-learning, the students also attributed the ability to implement a high degree of self-organization of educational activities and independence (30 $\%$ of respondents) and the absence of time and spatial restrictions (14\% of respondents). However, since less than half of the students noted a high degree of independence in learning new educational material as an advantage, it proves the above-mentioned teachers' indication that not all the students have a high level of conscious attitude to learning. To maintain the motivation of students for independent work, the teacher must constantly monitor educational activities and advise students on the rational distribution of time for studying educational material.

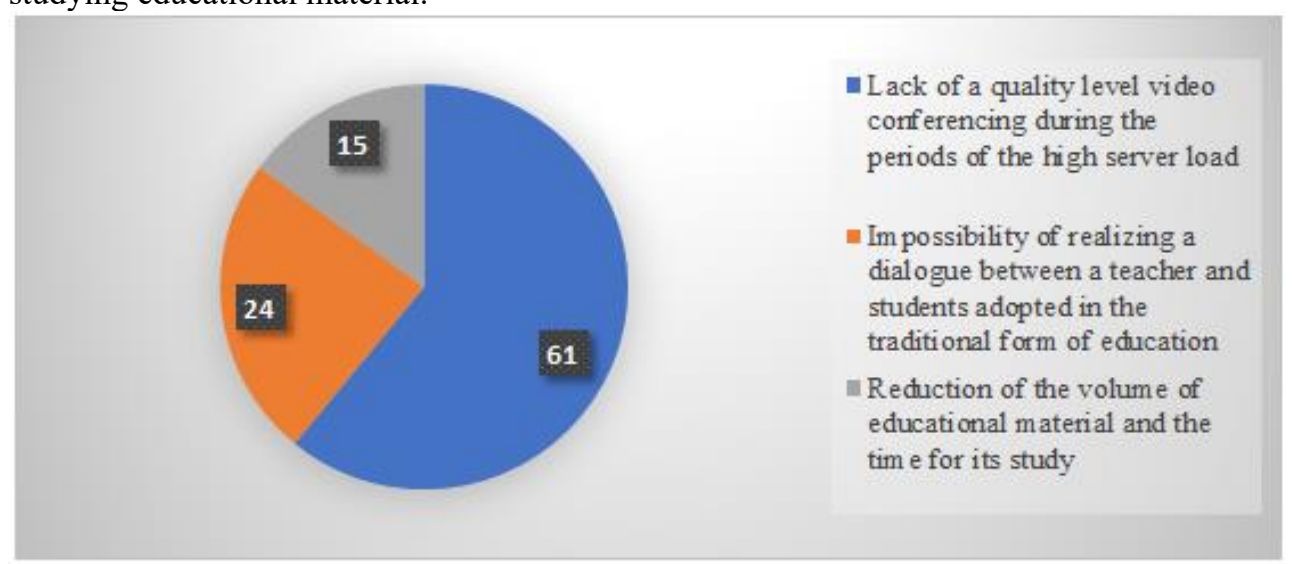

Fig. 2. The most important disadvantages of mastering the educational program in the remote mode from the point of view of the students of the Academy of Management of the Ministry of Internal Affairs of Russia.

Among the most important disadvantages of mastering the educational program in elearning mode, the students of the Academy indicated the lack of a high-quality level of video conferencing during periods of high server load (61 \% of respondents); the 
impossibility of realizing a dialogue between the teacher and students, adopted in the traditional form of education (30\% of respondents); reduction in the volume of educational material and the time spent on its studying (14\% of respondents). Such an assessment of the students certainly requires finding solutions to a number of important problems on the part of both the management and the teaching staff of an educational organization.

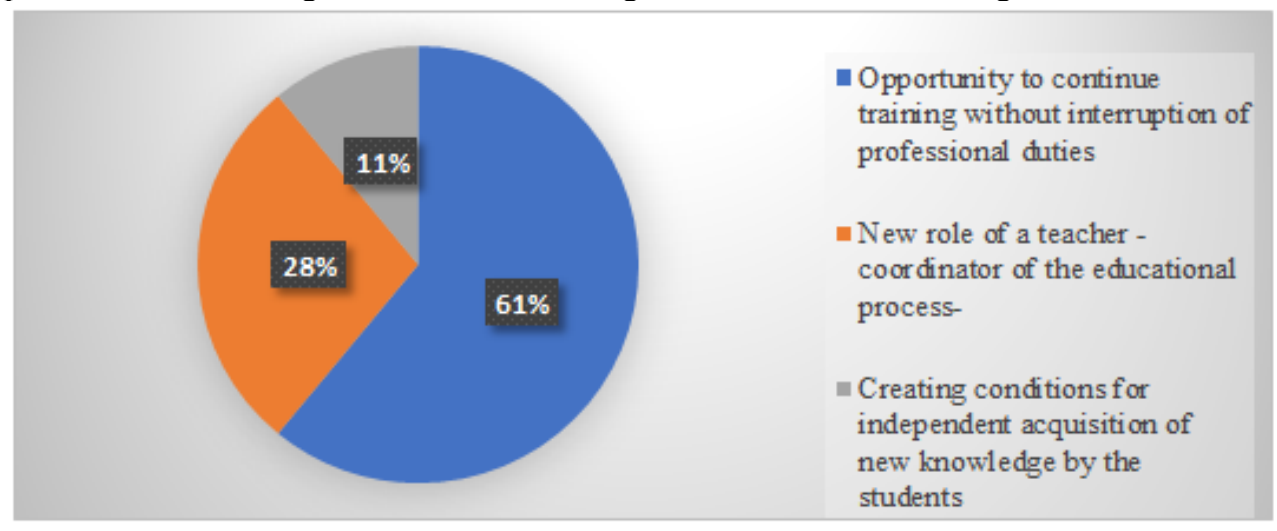

Fig. 3. The most important advantages of mastering the educational program in the remote mode from the point of view of the teachers of the Academy of Management of the Ministry of Internal Affairs of Russia.

As it can be seen from the above diagram, the representatives of the teaching staff of the Academy shared the students' opinion that the possibility of organizing the educational process without interrupting students from their professional duties is the most valuable advantage of creating a digital educational environment for police leaders $(61 \%$ of the respondents).

Among the most important advantages of e-learning, the teachers also identified the opportunity to participate in the educational process as a coordinator of educational activities (28\% of the respondents). It should be noted that the organization of joint educational activities (partnership between a teacher and students in the course of educational activities) is in full compliance with the andragogical principles of adult education and is a necessary condition for improving the quality of the formation of general educational and professional competencies of police leaders in a higher education institution.

In the course of the survey, $11 \%$ of the respondents pointed out the possibility of creating conditions for students to independently acquire new knowledge as one of the most important advantages of organizing a digital educational environment for police leaders. From our point of view, this is another confirmation of the statement made by the Russian researcher A.A. Andreev, who identified distance learning as the most adequate process for implementing the principle of lifelong education [27]. 


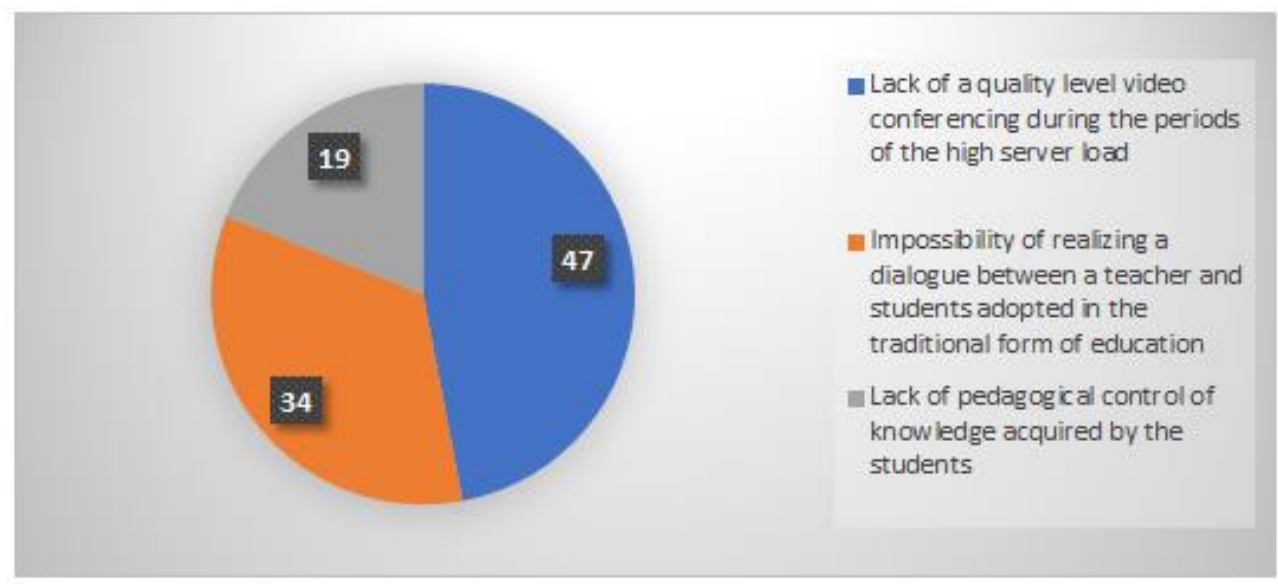

Fig. 4. The most important advantages of mastering the educational program in the remote mode from the point of view of the teachers of the Academy of Management of the Ministry of Internal Affairs of Russia.

As it can be seen from the diagram in figure 2, the Academy teachers, as well as the students, indicated the lack of a high-quality level of video conferencing during the periods of high server load as one of the most important disadvantages of creating a successful digital educational environment for police leaders ( $47 \%$ of the teachers compared to $61 \%$ of the students).

The Academy teachers and students both agreed that another negative aspect of eeducation for police leaders is the impossibility of realizing a dialogue between a teacher and students, adopted in the traditional form of education (34\% of the teachers compared to $24 \%$ of the students).

Given that the Academy teachers were dissatisfied with the pedagogical monitoring of the students' current and final academic performance in the remote mode, no wonder they came to the conclusion that the third disadvantage of the unplanned transition to e-learning was the lack of the sufficient pedagogical control of the knowledge received by the students during the implementation of the e-learning course (19\% of the respondents).

Thus, it becomes obvious that the problem of ensuring the stable functioning of the information and communication system of video conferencing still remains relevant for creating a successful digital educational environment in any higher education institution. On the other hand, the results obtained make it necessary to develop an innovative model for the transfer of educational information in a remote mode, designed to ensure an organic and emotionally colored relationship of all the participants of the educational process. Particular attention should be paid to the development of a control system for the assessment of the students' educational results and the evaluation of the level of formation of their educational and professional competencies within the framework of distance learning.

\section{Conclusions}

The emergency transition to distance learning in the context of the coronavirus pandemic has marked a change in the approaches to the implementation of educational programs by the departmental higher education institutions. The need to create a successful digital educational environment for police managers has set a number of tasks for the academic 
staff and required new skills from both, the educators and the students of the Academy of Management of the Internal Affairs of Russia. The development of innovative pedagogical technologies made it possible to achieve significant progress in the field of digital learning and opened way to such positive aspects of e-learning as the possibility of organizing the educational process without interrupting students from their professional duties and creating conditions for the students' self-study without time and spatial restrictions.

However, the research has specified some negative aspects of the unplanned arrangement of teaching higher educational programs which should be a matter of concern for the teaching staff of any higher education establishment. The experience obtained as a result of the study allows us to draw the conclusion that to overcome the drawbacks, we need

- to ensure the stable functioning of the information and communication system of video conferencing relevant for creating a successful digital educational environment in any higher education institution;

- to provide conditions for improving the teachers' practical skills to work in a distance mode;

- to develop a concept and methodology for a distance learning course and conduct practical testing of teaching materials, curriculum plans and self-study materials, specifically designed for use in a digital educational environment;

- to create effective models of multimedia presentation of educational materials for a distance learning course;

- to develop a high-quality pedagogical monitoring of the acquired knowledge, including the creation of means of control over the development of competencies within the framework of e-learning course;

- to develop methods of increasing the level of self-organization of students to form their skills for independent acquisition of knowledge and motivation to obtain high educational results;

- to reconsider the role of a teacher in the organization and realization of the e-learning course, drawing attention to the need of a closer communicative interaction with the students of the group.

Summing up, it should be recognized that the experience of emergency organization of e-learning for the students of the Academy of Management of the Ministry of Internal Affairs of Russia has not only changed the idea of the forms and models of education provision in the future, but also has made it possible to identify problematic issues of creating a digital educational environment in a higher education institution and outline some ways of their solution.

\section{References}

1. A. Urintsov, V. Dik, N. Dneprovskaya,. Individual learning trajectories as a key educational tool in the information society. Smart Digital Futures. Amsterdam: IOS Press BV, 652-657, (2014).

2. A.L. Nazarenko. Informatizatsiya obrazovaniya: sintez traditsionnogo i elektronnogo obucheniya (opyt sozdaniya novoy modeli lektsionnogo kursa). [Informatization of education: synthesis of traditional and e-learning (experience of creating a new model of a lecture course)]. Otkrytoye obrazovaniye. Nauchno-prakticheskiy zhurnal [Open Education. Scientific and practical journal], 2 (109), 71-72, (2015).

3. O.M. Babanskaya, G.V. Mozhaeva, V.A. Serbin A.V, Feshchenko. Sistemnyy podkhod $\mathrm{k}$ organizatsii elektronnogo obucheniya $\mathrm{v}$ klassicheskom universitete. [A systematic approach to the organization of e-learning in a classical university]. Otkrytoye 
obrazovaniye. Nauchno-prakticheskiy zhurnal. [Open education. Scientific and practical journal], 2, 63-69, (2015).

4. N. Matveeva, I. Abramova, A. Ananyina, E. Shihmolina, N. Medvedeva, I. Mazaeva, A. Korenev, N. Tsvetkova. The magic of innovation. New techniques and technologies in teaching foreign languages. London: Cambridge press, (2015).

5. T.P. Skorikova, S.S. Khromov, N.V. Dneprovskaya. Distance learning in scientific and professional fields of communication (interdisciplinary approach). Internet Journal of Environmental Science Education, 11 (10), 3467-3476, (2016).

6. I.A. Leontyeva. Distantsionnoye obucheniye kak odno iz sredstv povysheniya kachestva obrazovaniya studentov v vuze. [Distance learning as one of the means of improving the quality of student education at a university]. Vestnik Chelyabinskogo gosudarstvennogo pedagogicheskogo universiteta [Bulletin of the Chelyabinsk State Pedagogical University], 6, 84-88, (2017).

7. T.M. Lomonosova. Digital learning resources: Enhancing efficiency within blended higher education. Novosibirsk State Pedagogical University Bulletin, 8 (6), 124-137, (2014). http://en.vestnik.nspu.ru. DOI: 10.15293/2226-3365.1806.08. Retrieved on October, 21, (2020).

8. L.B. Osipova, O.M. Goreva. Distantsionnoye obucheniye v vuze: modeli i tekhnologii. [Distance learning at a university: models and technologies]. Sovremennyye problemy nauki i obrazovaniya [Modern problems of science and education], 5, (2014) https://www.science-education.ru/ru/article/view?id=14612. Retrieved on November, $8,(2020)$.

9. O.V. Kuznetsova. Distantsionnoye obucheniye: za i protiv. [Distance learning: pros and cons]. Mezhdunarodnyy zhurnal prikladnykh i fundamentalnykh issledovaniy. [International Journal of Applied and Basic Research], 8 (part 2), 362-364, (2015).

10. N.M. Pavlutskaya, L.V. Dubitskaya.. Primeneniye distantsionnogo obucheniya v sovremennom vuze (iz opyta raboty). [The use of distance learning in a modern university (from work experience)]. Mezhdunarodnyy nauchno-issledovatelskiy zhurnal [International scientific research journal], 3 (45), Part 4 March, 31-34, (2016).

11. C. White. Distance learning of foreign languages. Language Teaching, 39, 247-264, (2006). doi:10.1017/ S0261444806003727.

https://www.washington.edu/oea/pdfs/course_eval/FormI.pdf. Retrieved on October, 14, (2020).

12. C. R. Sole, J. Hopkins. Contrasting Two Approaches to Distance Language Learning. Distance Education, 28(3), 351-370, (2007). DOI: 10.1080/01587910701611369.

13. J. Hanson. Displaced but not replaced: the impact of e-learning on academic identities in higher education. Teaching in Higher Education, 14 (5), 553-564, (2009).

14. A. T. Mohr, D. Holtbrügge, N. Berg. Learning style preferences and the perceived usefulness of e-learning. Teaching in Higher Education, 17 (3), 309-322, (2012).

15. M.A. Peters, P. Jandric. Dewey`s Democracy and Education in the age of digital reason: the global, ecological and digital turns. Open Review of Educational Research, 4 (1), 205-218, (2017). DOI: https://doi.org/10.1080/23265507.2017.139529016. Retrieved on November, 8, (2020).

16. O. Schneider. A concept to simplify authoring of adaptive hypermedia e-learning structures. Interactive Learning Environments, 26 (6), 760-775, (2018). DOI: https://doi.org/10.1080/10494820.2017.1412987. Retrieved on November, 11, (2020).

17. M-C. Tsai, C-W. Tsai. Applying online externally-facilitated regulated learning and computational thinking to improve students' learning. Universal Access in the 
Information Society, 17 (4), 811-820, (2018). DOI: https://doi.org/10.1007/s10209017-0542-z. Retrieved on October, 14, (2020).

18. K.A. Jones, R.S. Sharma. An experiment in blended learning: Learning without lectures. IEEE Conference on e-Learning, e-Management and e-Services (IC3e), 1-6, (2017). DOI: https://doi.org/10.1109/IC3e.2017.8409229. Retrieved on October, 14, (2020).

19. Q. Wang, C. Huang. Pedagogical, social and technical designs of a blended synchronous learning environment. British Journal of Educational Technology, 49 (3), 451-462, (2018). DOI: https://doi.org/10.1111/bjet.12558. Retrieved on October, 14, (2020).

20. R. S. Baragash, H. Al-Samarraie. Blended learning: Investigating the influence of engagement in multiple learning delivery modes on students' performance. Telematics and Informatics, 35 (7), 2082-2098, (2018). DOI:

https://doi.org/10.1016/j.tele.2018.07.010. Retrieved on October, 14, (2020).

21. C. Hilgenberg \& W. Tolone. Student perceptions of satisfaction and opportunities for critical thinking in distance education by interactive video. The American Journal of Distance Education, 14 (3), 59-73 (2000).

22. N. Sampson. Meeting the Needs of Distance Learners. Language, Learning \& Technology, 7(3), 103-118, (2003).

23. A.H. Işık, R. Karakış \& I. Güler. Postgraduate students' attitudes towards distance learning. Procedia Social and Behavioral Sciences, 9, 218-222, (2010).

24. M. Rashid, A.G. Khokhar \& A.A. Tahir. Learner's Attitude towards Printed Word in Distance Education. Journal of Educational Research, 16 (1), 106-111, (2013).

25. E. Emrah. Distance-education in foreign language teaching: evaluations from the perspectives of freshman students. Procedia - Social and Behavioral Sciences, 176, 390 - 397, (2015). https://doi: 0.1016/j.sbspro.2015.01.487. Retrieved on October, 14, (2020).

26. G. Pyrchenkova, E. Radchenko, M. Kozin. Creation of digital educational environment for police leaders. E3S Web of Conferences 210, 02004 (2020).https://doi.org/10.1051/e3sconf/202021002004

27. A.A. Andreyev. Stanovleniye i razvitiye distantsionnogo obucheniya v Rossii. [Formation and development of distance learning in Russia]. Otkrytoye obrazovaniye. [Open education], 10, 40-46, (2013). 